Sardinia can lay claim to neither the one interest nor the other, to any marked degree. Neither can we compare it with Iceland, or with Majorca, and perhaps the only special interest which belongs to it is the occurrence of large numbers of nuraghi-conical stone mounds of prehistoric construction, hollow within, and probably designed as tombs by "the earliest inhabitants of the island. These are scattered over the island in large numbers, particularly near Torralba.

In Roman times Sardinia never rose to much importance, hence the relics of that period are but few. The most important is an amphitheatre near Cagliari hewn out of the rock, the major axis of which is 153 feet in length, and the minor axis 98 feet. It is now in a very dilapidated condition, far more so indeed than that of Puzzuoli. There are also a few Roman tombs. The most remarkable is in a suburb of Cagliari called Santa Tenera, and it is known as the Grutta dessa Pibera, that is the Grotto of the Viper, from the serpents which are sculptured over the entrance. It was the tomb of Attilia Pamphilla, a noble Roman lady. On the walls there are some interesting inscriptions, which have been published by General $\mathrm{La}$ Marmora and by Muratori.

The few travellers who visit Sardinia nowadays are tempted rather by prospects of sport than by anything else. Moufflons still exist among the Gennargentu Mountains, also wild boar, and smaller game, but the amount of sport afforded by the island has been exaggerated, and the sportsman will commonly prefer to go to the north of Norway or to Iceland to running the risk of catching malarious fever in Sardinia.

Malaria has always been very prevalent in the island. There is a large extent of marsh land, and in the autumn a great deal of decomposing vegetable matter. We were glad to notice that some of the Englishmen who have recently acquired land in the island have not only commenced draining operations, but have also planted numbers of Eucalyptus trees, the effect of both operations being undoubtedly to diminish malaria. On the other hand, many of the native landowners are converting their timber into charcoal, for which they can obtain about fifty francs a ton in France and elsewhere. Some thousands of tons are annually shipped, and unfortunately new trees are not planted in place of the old ones. If this wholesale destruction of forests continues, there can be no doubt that the climate of the country will eventually be seriously affected. The exporters do not in the least realise that they are shipping vis viva in a very condensed form from their shores, and at the same time diminishing the rainfall.

The chief wealth of Sardinia lies in her mines of argentiferous galena, and of calamine. As much as 120 ounces per ton of silver have been extracted from some of the lead ores. The principal mines are those of Monte Poni, near Iglesias, in the south-west of the island, and of Monte Vecchio, in the west centre. At Monte Poni we noticed that the newest forms of Belgian and German machinery for crushing and washing the ores were in use. At the present time, the operations are very much impeded by the flow of water into the principal shaft, which will probably be to a great extent obviated, by boring a tunnel through the side of the mountain in which the shaft is sunk.

A railway constructed, and to a great extent owned by an English company, now connects the two capital cities of the island-Cagliari and Sassari-a distance of 260 kilometres, with branches to Iglesias, in the south-west, and to Terranova in the north-east, and the line is continued from Sassari for $12 \frac{1}{2}$ miles to Portotorres, its port, a miserable and fever-stricken village. Fifty years ago, there were scarcely any roads at all in Sardinia. The Roman roads had become obliterated, and no attempt had been made to construct them afresh.

The railway is well constructed, but the trains are extremely slow, and do not average more than seventeen miles an hour. Between Macomer and Chilirani there are many cuttings and some very steep gradients. The railway connecting the two capitals-Cagliari and Sassari - has only recently been completed. Sassari, a town of 33,000 inhabitants, is nearly as large as Cagliari, and in some respects preferable to it. It stands upon a hill 650 feet above the sea. It has a clean, bright appearance, but in reality is very badly drained and extremely unhealthy. So recently as I 855 the cholera carried off nearly one-third of the population in less than three weeks, at the rate of more than 500 a day.

In Torralba there are a number of nuraghi, and in the neigh bourhood several extinct volcanoes, the most important of which is Keremule. Nearly midway between Mores and Torralba we saw exposed, in a recent railway cutting, a fine mass of columnar basalt overlying chalk. There is a good deal of pale green, pale pink, and grey trachite in the neighbourhood. The only geological map of the island which now exists is in General La Marmora's fine monograph published in Paris and Turin between 1839 and I860, and entitled Voyage en Sardaigne.

G. F. RODWELL

\section{MATHEMATICS IN SCANDINAVIA ${ }^{1}$}

THE first part of the new mathematical journal has reached us. We have not quite reproduced the title; the words Zeitschrift herausgegeben von on one side of the axis of symmetry (let us say) of the page, are matched by the words Fournal rédigé par on the other side. This is significant of one part of the Editor's plan: the journal, though printed and published in Stockholm, is to have its articles written in what the Editor styles the principal languages. It may be that English is one of these languages; there is not, however, in the preface, anything definite to relieve our doubts. The prospectus (unintentionally, we hope) is somewhat more informatory. In the language of our "lucid" neighbours it says: "In Germany, in France, in Italy, in Scandinavia, everywhere in fact, where science is held in honour (other side of the line of symmetry-'iiberall wo mathematisches Leben herrscht'), the idea of starting the journal was received with the most lively sympathy." Apparently in regard to the English language and English science, the less said the better. We, for our part, say nothing.

In outward appearance the new journal closely resembles Crelle's. The paper is equally good, the margin equally broad, and the size of page and the number of pages in a part substantially the same in the two serials. Neither is quite so handsome as a third member of the same family, the now five-year old American Fournal of Mathematics; but then we must not forget the ratio of five dollars to twelve marks.

The list of the editorial staff supporting M. MittagLeffler contains many distinguished names. There are five Swedish mathematicians, four Norwegians, three Danish, and one from Finland; and scarcely one of these but is well known far beyond his native country.

The contents of the first part are all that could be expected from such a brotherhood, headed by such a chief. The first paper is by Prof. Poincaré, of Paris, its subject being the Théorie des groupes fuchsiens. It extends to $62 \mathrm{pp}$., and is altogether worthy of its place of honour. One does not know which to admire most-the author's grasp of his subject, or the clearness and simplicity of his exposition. Following this, comes a contribution of 14 pp. by Prof. Malmsten, of Upsala, "Zur Theorie der Leibrenten;" then there is a paper of $16 \mathrm{pp}$. on "Eine Annäherungsmethode im Probleme der drei Körper," by M. Gylden, the head of the Stockholm Observatory; and lastly, to complete the 96 pages, there is

I Acta Mathematica: $Z$-itschrif herausgegeben, von G. Mittag-Leffler. (Stockholm, x882.) 
a short communication entitled "Das Problem der Configurationen," by Prof. Reye, of Strassburg. The Editor may be most heartily congratulated on the start he has made: taking everything into account, we have little doubt but that his efforts will be crowned with abundant success.

The most serious difficulty about such an undertaking is that of finance. The American Journal began its career with the Johns Hopkins trustees at its back: we suppose, however, that by this time it walks alone. In the present instance, the mainstay is the enlightened King Oscar the Second. Long may he live! The journal is rightly dedicated to him, the dedication being made appropriately in one of the second-rank languages, which it is cheering for us to see, have sometimes their uses.

M. D.

\section{THE FRENCH MISSION TO CAPE HORN}

7 HE members of the French Magnetic and Meteorological Expedition to Cape Horn have taken up their quarters at Crange Bay, and have already begun work. The accompanying illustration, reproduced from La Nature, after a photograph transmitted to the Paris Academy of Sciences, will give an idea of the aspect of the station occupied by the expedition. On the summit of the hill are the astronumical cabins, beside which are placed a pluviometer and an actinometer. The large house in the middle distance forms the officers' quarters, while the lower building is for the sailors, Along the shore are other structures partly shown in the illustration, a stockade for the tidal register, and an isolated tent for absolute determinations.

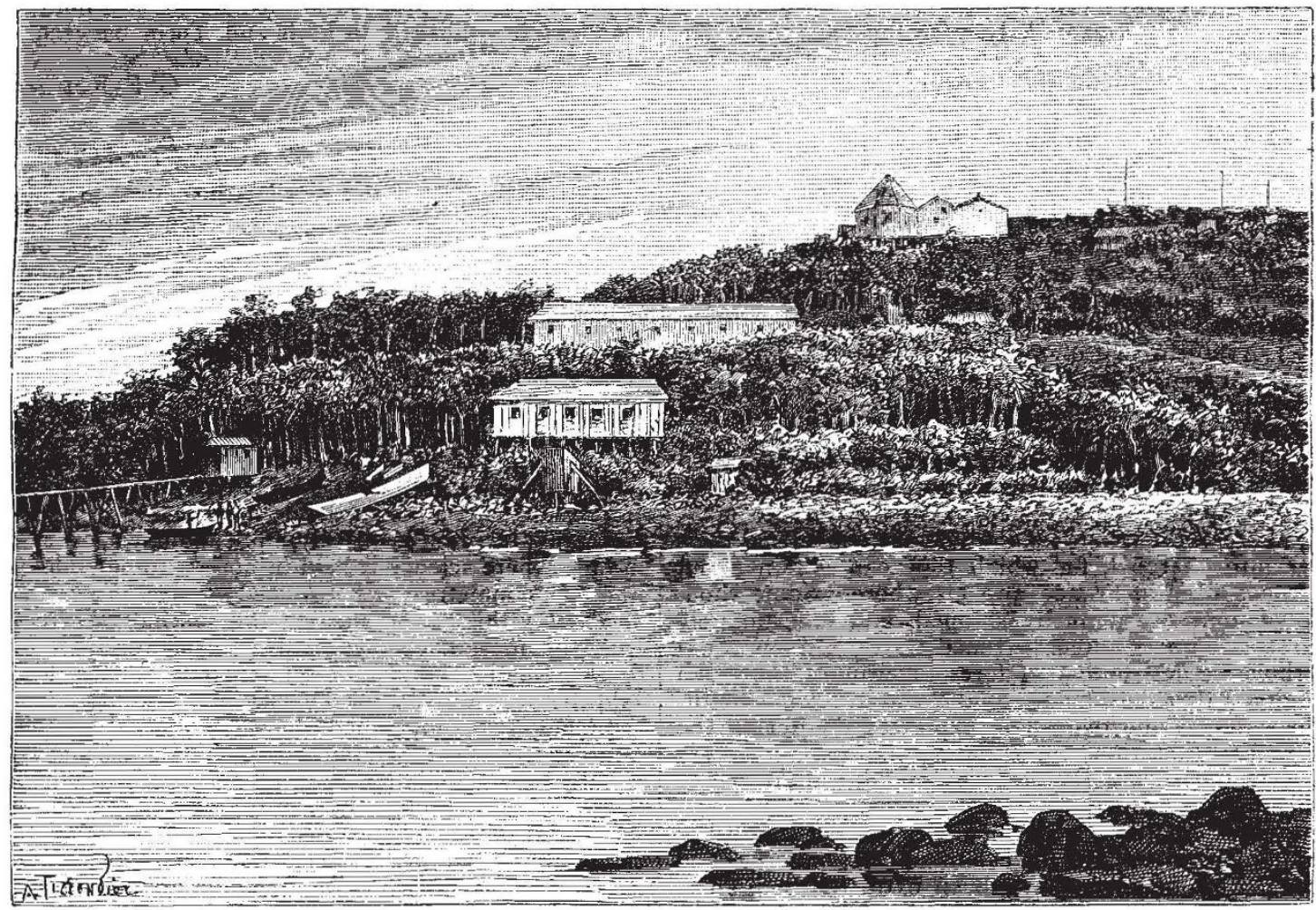

Station of the French Mission to Cape Horn.

The mission arrived at Orange Bay, Terra del Fuego, on September 6 last. Tł.ey found the country marshy, and were compelled to select a wooded spot in order to obtain firm ground. No time was lost in erecting inclosings and installing the various instruments; and on September 26, the meteorological and magnetical observations were begun. Since the arrival of the party the temperature at Orange Bay has been very mild; the thermometer has never been below $0^{\circ} \mathrm{C}$., and several times it has been as high as $16^{\circ}$. The air is very moist, and there has been plentiful rain almost every day, though not lasting long. Squalls have been rare. The magnetic observations will be made partly by instruments which will be read directly, - absolute determinations of declination, inclination, horizontal force, \&c., and partly by means of regulating apparatus, which, so far, have worked very satisfactorily, and bave given indications agreeing with those obtained from direct-reading mag- netometers. The other duties of the expedition consist in astronomical and meteorological observations.

The expedition has been well received by the natives, one of whom speaks and reads English fluently. Indeed, twenty miles off, in Beagle Channel, is an English mis. sion station, which is reported to be very prosperous. On the whole, the French expedition has been very successful ; it may be regarded as one of the International Polar Observing Stations.

\section{HEATING BY ACETATE OF SODA}

M A. ANCELIN, Civil Engineer, describes in $L a$ N1. Nature a method he has devised of heating for do. mestic purposes, travelling, \&c. , by means of acetate of soda. His object has been to deyise a method that will possess all the advantages of heating by means of hot water, without any of its inconveniences. For this purpose he sought 